Article

\title{
Transferring a Biomass Enhancement Biotechnology from Glasshouse to Field: A Case Study on Wheat GWD RNAi
}

\author{
Alex P. Whan, Arunas P. Verbyla, Jos C. Mieog, Crispin A. Howitt and Jean-Philippe Ral * \\ CSIRO Food Futures National Research Flagship, GPO Box 1600, Canberra, ACT 2601, Australia; \\ alex.whan@CSiro.au (A.P.W.); ari.verbyla@csiro.au (A.P.V.); Jos.Mieog@csiro.au (J.C.M.); \\ Crispin.howitt@csiro.au (C.A.H.) \\ * Correspondence: jean.ral@csiro.au; Tel.: +61-2-6246-5245; Fax: +61-2-5246-5345
}

Received: 27 October 2017; Accepted: 6 December 2017; Published: 8 December 2017

\begin{abstract}
In glasshouse studies we have previously shown that endosperm-specific RNAi suppression of the primary starch phosphorylation enzyme, Glucan, Water Dikinase (GWD) leads to enhanced early vigor, greater leaf biomass, and increases in both head size and yield. To confirm these affects in a field setting, trials were conducted in three Australian environments. Field results were consistent with those in the glasshouse for increased flag leaf area and rachis nodes. However, there was also a decrease in tiller number and consequently a decrease in yield for one event at two sites. These findings provide potentially important information on plant vigor enhancement and highlight the challenges of transferring the modification of complex traits from single plants in controlled environments to the field.
\end{abstract}

Keywords: field trial; biomass; wheat; GWD; starch; phosphate; head architecture

\section{Introduction}

Wheat has been an important component of the human diet for thousands of years. Wheat has been found in human settlement pits over 8000 years old [1]. The demand for staple crop products is predicted to grow by $60 \%$ by 2050 , with major increases occurring in the next 20 years, while the production area is likely to increase by only $10 \%$ over the same period [2]. With around 750 million tons produced each year worldwide, wheat is (after maize) the second most produced food among the cereal crops. Improving yield potential in this major crop is an important research challenge.

Many tools from soil preparation and seed placement at planting time, use of crop rotation and fertilizers, advances in harvesting methods to marker-assisted selection, genetic introgression and hybrid technology have been applied to improve the agronomic performance of cereals $[3,4]$. The recent emergence of gene editing technology provides another potential tool for increasing productivity to match the predicted demand [5], as long as suitable targets for editing are identified to provide yield increases.

While no Genetically Modified (GM) traits have been commercialized in wheat, significant investment has been made towards improving its agronomic performance. In wheat, starch makes up over $70 \%$ of total grain dry weight and provides the energy required by the embryo to fuel metabolic processes during the first days of grain germination [6,7]. Therefore, starch has been considered one of the primary targets for agronomic performance enhancement. A prominent example is the endosperm-specific over-expression of the large subunit of ADP-glucose Pyrophosphorylase (AGPase) in wheat, leading to increased plant biomass and seed yield in glasshouse experiments [8-11].

We have developed transgenic wheat lines with endosperm-specific downregulation of a primary enzyme involved in starch degradation, Glucan, Water Dikinases (GWD) [12]. The dikinases, 
including GWD, and Phosphoglucan, Water Dikinase (PWD), along with the phosphatases (Starch Excess4 (SEX4), LikeSexFour1 and 2 (LSF1 and 2)), modify the level of phosphate groups in starch [13-16], allowing access to degradative enzymes including Endo $(\alpha)$ and Exo $(\beta)$ amylases [16].

Although the involvement of starch phosphorylation in transitory starch catabolism has been extensively studied [17], the importance of phosphoglucans in cereal endosperm is yet to be fully understood. Using an RNAi approach and a grain-specific promoter (the high molecular weight glutenin Bx17 promoter) [12], we suppressed GWD expression in the endosperm of developing wheat grain. Unexpectedly, we also observed that in glasshouse studies inactivation of GWD in the endosperm of wheat led to increases in early vigor, plant biomass and yield, associated with alteration of head architecture including head size in a single-pot glasshouse trial. The increase in coleoptile length was observed from an early stage and maintained throughout plant development in all glasshouse studies [7].

Here we provide results from field trials of GWD RNAi wheat performed in three Australian environments, and discuss the importance of measuring transgenic traits in real-world settings.

\section{Results and Discussion}

The effect of GWD RNAi on yield at a plot level was different to the observations made of single plants in a controlled environment. Although there was a trend for increased yield in one of the three environments (Narrabri NSW), yield was not significantly increased at any site (Figure 1). For TaGWD4-7, the yield was significantly $(p<0.05)$ reduced at both Ginninderra and Merredin. This is in contrast to previous glasshouse results where increases in yield were observed [12]. It should be noted that yield comparisons can only be made within sites, as different harvesting equipment and techniques were used at each site.

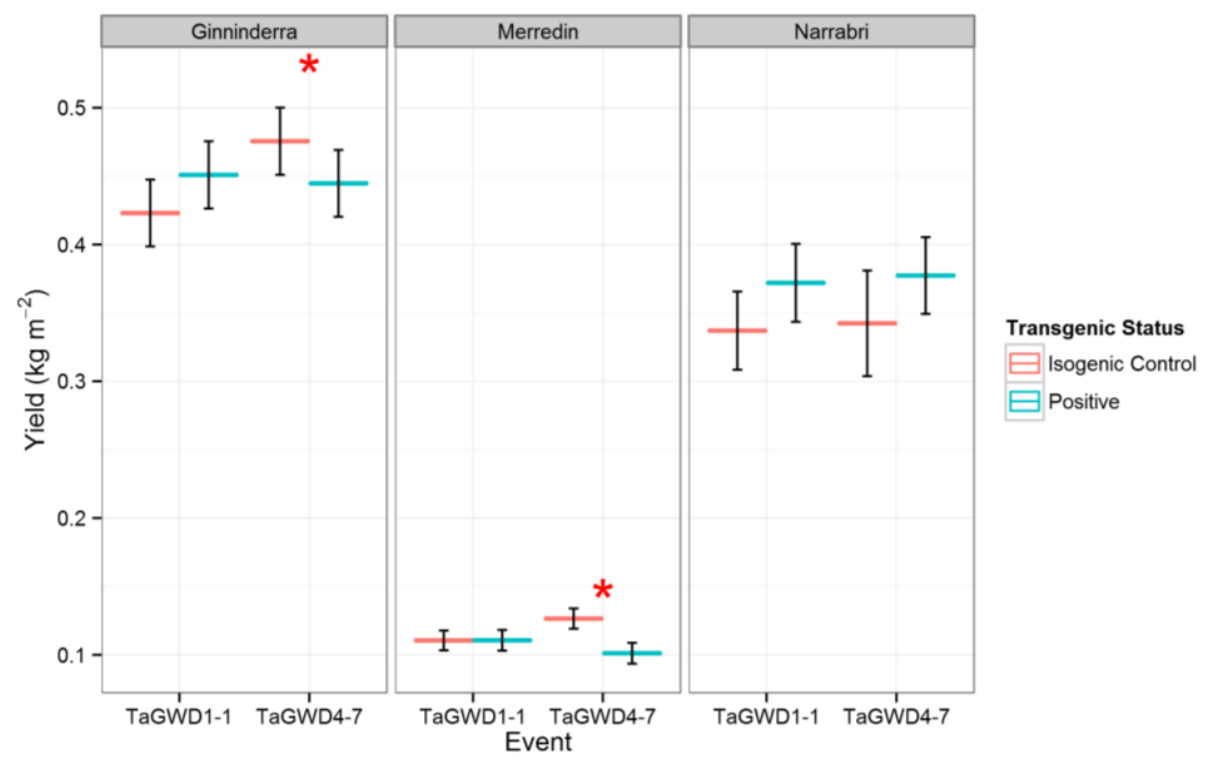

Figure 1. Yield for GWD RNAi lines and their isogenic controls at three sites. Significance for a pairwise comparison at $p<0.05$ is shown by *.

Tiller number was reduced in the positive lines in all three environments, suggesting a direct and relatively straightforward effect of GWD downregulation on gross plant architecture. At all sites, negative segregant lines had a higher tiller number than positive lines (Figure 2). This effect was significant $(p<0.05)$ for both TaGWD1-1 and TaGWD4-7 at Ginninderra, and for TaGWD4-7 at Narrabri. Despite the reduction of tiller number in the transgenic lines, there were no significant changes in groundcover during early development (Z14) at Narrabri, measured as NDVI (Table A1) or for biomass at harvest at either Narrabri or Ginninderra (Figure 3). At Merredin, positive lines had 
decreased plot biomass for both events, although the difference was only significant for TaGWD4-7 $(p<0.05$, Figure 3). In isolation, a reduction in tiller number is deleterious for biomass and yield, since there are fewer spikes to produce grain. The absence of yield enhancement observed in the field can most easily be accounted for by a consistent reduction in tiller number in the field-a response not observed in glasshouse studies. The reduction of tiller number in the transgenic lines observed at anthesis was confirmed at harvest, as head number per unit area, as determined from the harvest cuts, was also reduced in comparison to the controls.

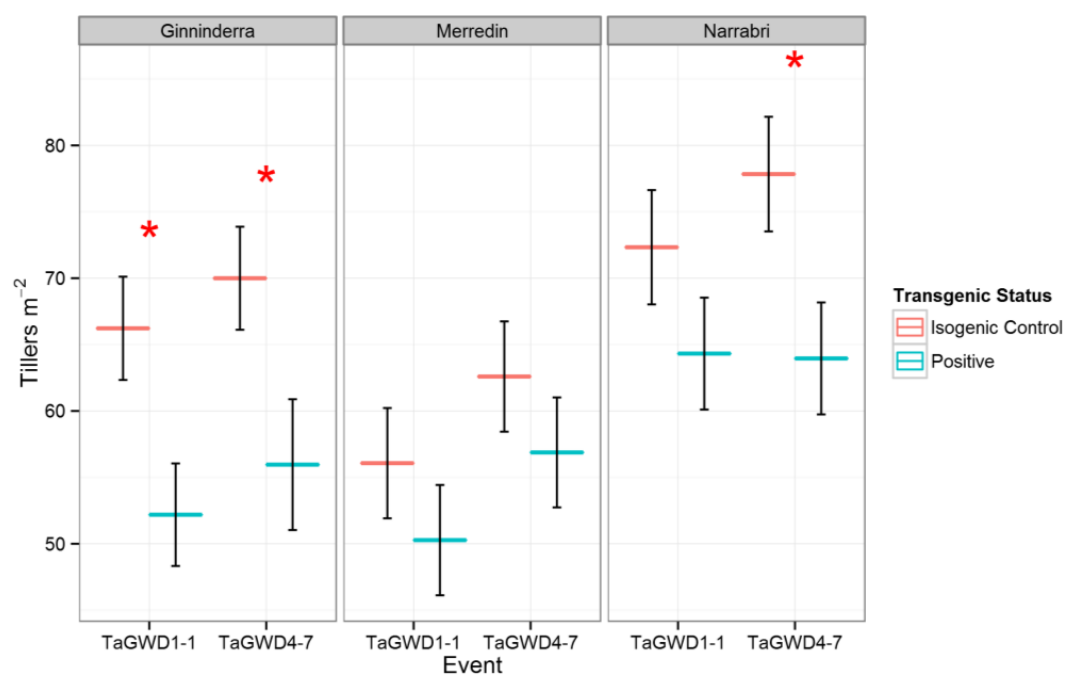

Figure 2. Tiller counts for GWD RNAi lines and their isogenic controls at three sites. Significance for a pairwise comparison at $p<0.05$ is shown by *



Figure 3. Estimated plot biomass for GWD RNAi lines and their isogenic controls at three sites. Significance for a pairwise comparison at $p<0.05$ is shown by *.

Despite these differences between the glasshouse and the field, the effects of GWD RNAi on certain traits were maintained between glasshouse and field studies. At the Narrabri site, flag leaf area was significantly increased in positive lines ( $p<0.005$, Figure 4$)$, showing a consistent effect of GWD RNAi between the glasshouse and the field, and is a further indication of the direct effect of GWD RNAi on plant architecture. Leaf area was not measured at other sites. Similarly, spike architecture was altered in the positive lines, with a consistent trend of increased rachis nodes at Ginninderra 
(the only site measured), and a significant increase for TaGWD1-1 $(p<0.05$, Table A1). The alteration of spike architecture appears to be a means by which GWD RNAi lines are able to increase yield potential, by increasing the number of seeds per spike. In the previous glasshouse work, the increased yield potential was the result of a combination of an increase in head number, head size and grain weight. Data from these trials have shown that in field conditions, GWD RNAi technology consistently reduces the tiller number, thereby reducing one yield component. However, in certain conditions, GWD RNAi lines also have the potential to produce more seeds per spike, potentially overcoming the reduced number of tillers to increase yield.

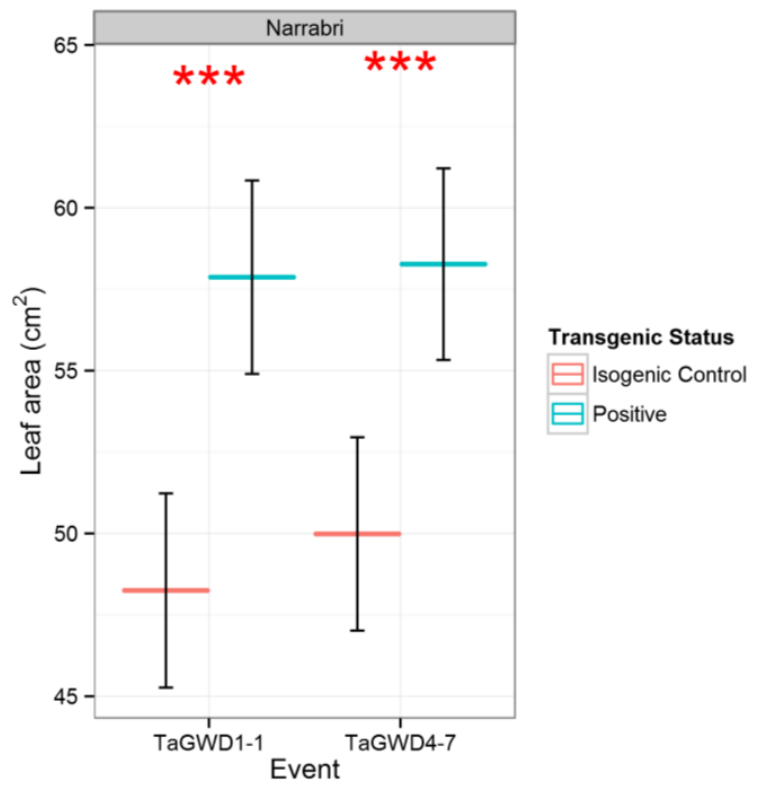

Figure 4. Flag leaf area for GWD RNAi lines and their isogenic controls at Narrabri. Significance at $p<0.005$ is shown by ***

Despite the use of an endosperm-specific promoter, increases in biomass were found for GWD RNAi lines during development in the glasshouse. While similar biomass increases were not identified in field conditions, the effect on tillering suggests that the presence of the RNAi construct is still affecting plant growth during development and is not limited to effects on grain development.

There appears to be a strong environmental effect on the GWD RNAi phenotype. In the highly controlled glasshouse environment, when resources were not limited, no difference in tiller number was found, while the field results showed a consistent and clear reduction. Between the field sites there were also clear differences. Narrabri, where conditions were least limiting, was the site with the most positive yield outcome for GWD RNAi lines, where a consistent but non-significant increase was found. When resources or environmental conditions were more limiting, like at Ginninderra or more in the semi-arid Western Australian region of Merredin, it seems that the GWD RNAi lines were unable to overcome the effect of reduced tillering. Manipulation of the carbohydrate pathway may have impacted source/sink relationship [10,18]. Transgenic plants might have an altered response to carbon allocation when resources become scarce.

Further work on this technology should therefore focus on the cause of reduced tillering, and identifying the factors that limit the maximum seed fill of which this technology is capable.

For GM traits, as for any novel gene variation investigation, it has been demonstrated that the effect obtained in a highly controlled environment could differ drastically in more variable growing conditions [19]. We have shown this to be the case for GWD RNAi for overall yield, where the response was not only different to that in glasshouse conditions, but different in each environment. Such complexity of response is not surprising given that yield is made up of multiple components, 
each of which may be affected by the transgenic event and environment in different ways. However, we have also shown stability in certain traits between the glasshouse and the field, indicating a certain uniformity of response in plant architecture to GWD downregulation.

If agricultural production is to increase in an environment of growing pressures on land use, reduced availability of inputs, and increasing climate uncertainty, transgenic technologies must be considered. However, as we have highlighted in this work, it is critical that GM traits are studied in multiple environments that are as close as possible to production settings, especially for complex traits. It is also clear that improving yield for cereal crops through GM will require a clear understanding of the transgenic effect in the background germplasm, which may require specific breeding to overcome particular limitations, such as reduced tillering.

\section{Experimental Section}

\subsection{Field Design}

Field trials were conducted, under DIR (Dealing involving an Intentional Release of GMO inot the environement) licenses 099, 111 and 112 issued by the Office of the Gene Technology Regulator, during the growing season 2012/13 at three sites representing different growth environments for wheat: Narrabri (New South Wales, irrigated, very favorable conditions); Ginninderra Experimental Station (Australian Capital Territory, non-irrigated, limited conditions); and Merredin (Western Australia, low yielding conditions) (Table A2).

Each trial was a partially replicated, split plot design, with event and presence of the construct (positive vs. isogenic control) as the split plot treatment. Nitrogen treatments meeting standard agronomic practice for the region of the trial were applied at sowing and again just prior to anthesis.

\subsection{Measurements}

Flag leaf area was measured at anthesis, only at the Narrabri site. Ten flag leaves were selected at random from each plot, and measured with a CI-203 leaf area meter (CID Bio-Science, Camas, WA, USA). Tiller counts were taken at anthesis. The total number of stalks inside a $90 \mathrm{~cm}^{2}$ frame was counted in three locations per plot at each site.

Harvest cuts were taken at each site from two locations in each plot at each site. All stalks in a $90-\mathrm{cm}^{2}$ frame were cut at ground level and processed for biomass, harvest index and thousand grain weight in the laboratory. Rachis nodes were recorded for 10 randomly selected spikes from each harvest cut for events TaGWD1-1 and TaGWD4-7 from the Ginninderra site.

At the Narrabri site, plots were harvested by hand and processed on site with a mobile thresher. At Gininderra and Merredin, plots were machine harvested. Plot yield was standardized by dividing by plot area to calculate $\mathrm{kg} \cdot \mathrm{m}^{-2}$. Plot biomass was estimated by dividing plot yield by harvest index.

\subsection{Statistical Analysis}

Statistical analysis was performed in ASReml-R. All data were included in the analysis to maximize the spatial information. A base model treating event, construct presence, density and seed source as fixed effects and main plot and position as random effects was fitted. Spatial terms were fitted for each trait as appropriate. Least significant differences were only calculated for comparisons between the same background where the construct was both present and absent-events TaGWD1-1 and TaGWD4-7.

Acknowledgments: The authors acknowledge the Grains Research and Development Corporation of Australia for its financial support for the research; Richard Richards and Colin Cavanagh for input into experimental designs and for helpful discussions; Andreas Hundt, Geoff Ellacott and Freddie Loyman for their technical assistance; and Russell Heywood, Phil Dunbar, Byron Cochran, Matt Lynch, Greg Constable, Shiming Liu, Chris Tyson, Warwick Stiller, and Mick Poole for assistance with the field trials. 
Author Contributions: A.P.W. was involved in the experimental design, data collection, data analysis and writing of the manuscript. A.P.V. was involved in the experimental design and data analysis. J.C.M. was involved in the data collection and writing of the manuscript. C.A.H. was involved in data collection and writing of the manuscript. J.-P.R. was involved in the experimental design, data collection and writing of the manuscript.

Conflicts of Interest: The authors declare no conflict of interest.

\section{Appendix A}

Table A1. Yield components.

\begin{tabular}{|c|c|c|c|c|c|c|}
\hline \multirow{2}{*}{ Trait (Units) } & \multirow{2}{*}{ Event } & \multirow{2}{*}{ Site } & \multicolumn{2}{|c|}{ Negative Segregant } & \multicolumn{2}{|c|}{ GWD RNAi } \\
\hline & & & Mean & SE & Mean & SE \\
\hline TGW (g) & G1.1 & GES & 40.05 & 2.55 & 35.06 & 2.56 \\
\hline TGW (g) & G4.7 & GES & 40.12 & 2.54 & 36.63 & 2.51 \\
\hline TGW (g) & G1.1 & Merredin & 44.95 & 0.60 & 45.33 & 0.60 \\
\hline TGW $(\mathrm{g})$ * & G4.7 & Merredin & 43.20 & 0.60 & 45.36 & 0.60 \\
\hline TGW (g) & G1.1 & Narrabri & 42.90 & 0.73 & 43.45 & 0.73 \\
\hline TGW (g) & G4.7 & Narrabri & 42.71 & 0.73 & 43.48 & 0.73 \\
\hline HC biomass (g) & G1.1 & GES & 236.38 & 20.04 & 212.43 & 19.99 \\
\hline HC biomass $(\mathrm{g})$ & G4.7 & GES & 248.63 & 20.07 & 224.68 & 26.96 \\
\hline HC biomass (g) & G1.1 & Merredin & 319.75 & 21.03 & 278.55 & 21.03 \\
\hline $\mathrm{HC}$ biomass $(\mathrm{g}) *$ & G4.7 & Merredin & 342.18 & 21.03 & 293.59 & 21.03 \\
\hline HC biomass (g) & G1.1 & Narrabri & 303.77 & 25.27 & 320.78 & 40.72 \\
\hline HC biomass (g) & G4.7 & Narrabri & 303.77 & 25.27 & 339.1 & 25.3 \\
\hline Yield/spike (g) & G1.1 & GES & 1.59 & 0.06 & 1.54 & 0.06 \\
\hline Yield/spike (g) & G4.7 & GES & 1.58 & 0.06 & 1.52 & 0.1 \\
\hline Yield/spike (g) & G1.1 & Merredin & 1.42 & 0.06 & 1.38 & 0.06 \\
\hline Yield/spike (g) & G4.7 & Merredin & 1.33 & 0.06 & 1.45 & 0.06 \\
\hline Yield/spike (g) & G1.1 & Narrabri & 1.53 & 0.1 & 1.65 & 0.1 \\
\hline Yield/spike (g) & G4.7 & Narrabri & 1.62 & 0.1 & 1.77 & 0.11 \\
\hline Leaf area $\left(\mathrm{cm}^{2}\right)^{*}$ & G1.1 & Narrabri & 48.25 & 2.98 & 57.87 & 2.97 \\
\hline Leaf area $\left(\mathrm{cm}^{2}\right) *$ & G4.7 & Narrabri & 49.99 & 2.97 & 58.27 & 2.94 \\
\hline Rachis nodes * & G1.1 & GES & 18.26 & 0.24 & 19.32 & 0.24 \\
\hline Rachis nodes & G4.7 & GES & 18.33 & 0.24 & 18.67 & 0.24 \\
\hline NDVI (Z14) & G1.1 & Narrabri & 0.38 & 0.06 & 0.42 & 0.06 \\
\hline NDVI (Z14) & G4.7 & Narrabri & 0.44 & 0.06 & 0.37 & 0.06 \\
\hline
\end{tabular}

Table A2. Field trial information.

\begin{tabular}{cccc}
\hline Field Trial Characteristics & Narrabri (NSW) & Ginnindera (NSW) & Merredin (WA) \\
\hline Sowing density $\left(\right.$ seeds per $\left.\mathrm{m}^{2}\right)$ & 150 & 170 & 100 \\
\hline Plot size $\left(\mathrm{m}^{2}\right)$ & 10 & 10 & 8 \\
\hline Nitrogen application $\left(\mathrm{kg} \cdot \mathrm{Ha}^{-1}\right)$ & 40 (sowing) & 15 (sowing) & 7.5 (sowing) \\
\hline Planting date & 40 (anthesis) & 75 (anthesis) & 7.5 (anthesis) \\
\hline Emergence & $16 / 05 / 12$ & $11 / 06 / 12$ & $14 / 06 / 12$ \\
\hline Anthesis & $26 / 05 / 12$ & $26 / 06 / 12$ & $07 / 07 / 12$ \\
\hline Harvest & $11 / 10 / 12$ & $10 / 11 / 12$ & $07 / 09 / 12$ \\
\hline
\end{tabular}

\section{References}

1. Tanno, K.-I.; Willcox, G. How fast was wild wheat domesticated? Science 2006, 311, 1886. [CrossRef] [PubMed]

2. Godfray, H.C.J.; Beddington, J.R.; Crute, I.R.; Haddad, L.; Lawrence, D.; Muir, J.F.; Pretty, J.; Robinson, S.; Thomas, S.M.; Toulmin, C. Food Security: The Challenge of Feeding 9 Billion People. Science 2010, 327, 812-818. [CrossRef] [PubMed] 
3. Millet, E.; Rong, J.K.; Qualset, C.O.; Mcguire, P.E.; Bernard, M.; Sourdille, P.; Feldman, M. Grain yield and grain protein percentage of common wheat lines with wild emmer chromosome-arm substitutions. Euphytica 2014, 195, 69-81. [CrossRef]

4. Yang, Z.; Bai, Z.; Li, X.; Wang, P.; Wu, Q.; Yang, L.; Li, L.; Li, X. SNP identification and allelic-specific PCR markers development for TaGW2, a gene linked to wheat kernel weight. Theor. Appl. Genet. 2012, 125, 1057-1068. [CrossRef] [PubMed]

5. Uauy, C. Wheat genomics comes of age. Curr. Opin. Plant Biol. 2017, 36, 142-148. [CrossRef] [PubMed]

6. Whan, A.; Dielen, A.S.; Mieog, J.; Bowerman, A.F.; Robinson, H.M.; Byrne, K.; Colgrave, M.; Larkin, P.J.; Howitt, C.A.; Morell, M.K.; et al. Engineering alpha-amylase levels in wheat grain suggests a highly sophisticated level of carbohydrate regulation during development. J. Exp. Bot. 2014, 65, 5443-5457. [CrossRef] [PubMed]

7. Bowerman, A.F.; Newberry, M.; Dielen, A.; Whan, A.; Larroque, O.; Pritchard, J.; Gubler, F.; Howitt, C.A.; Pogson, B.J.; Morell1, M.K.; et al. Suppression of glucan, water dikinase in the endosperm alters wheat grain properties, germination and coleoptile growth. Plant Biotechnol. J. 2016, 14, 398-408. [CrossRef] [PubMed]

8. Smidansky, E.D.; Clancy, M.; Meyer, F.D.; Lanning, S.P.; Blake, N.K.; Talbert, L.E.; Giroux, M.J. Enhanced ADP-glucose pyrophosphorylase activity in wheat endosperm increases seed yield. Proc. Natl. Acad. Sci. USA 2002, 99, 1724-1729. [CrossRef] [PubMed]

9. Smidansky, E.D.; Meyer, F.D.; Blakeslee, B.; Weglarz, T.E.; Greene, T.W.; Giroux, M.J. Expression of a modified ADP-glucose pyrophosphorylase large subunit in wheat seeds stimulates photosynthesis and carbon metabolism. Planta 2007, 225, 965-976. [CrossRef] [PubMed]

10. Tuncel, A.; Okita, T.W. Improving starch yield in cereals by over-expression of ADPglucose pyrophosphorylase: Expectations and unanticipated outcomes. Plant Sci. Int. J. Exp. Plant Biol. 2013, 211, 52-60. [CrossRef] [PubMed]

11. Kang, G.; Liu, G.; Peng, X.; Wei, L.; Wang, C.; Zhu, Y.; Ma, Y.; Jiang, Y.; Guo, T. Increasing the starch content and grain weight of common wheat by overexpression of the cytosolic AGPase large subunit gene. Plant Physiol. Biochem. PРB 2013, 73, 93-98. [CrossRef] [PubMed]

12. Ral, J.-P.; Bowerman, A.F.; Li, Z.; Sirault, X.; Furbank, R.; Pritchard, J.R.; Bloemsma, M.; Cavanagh, C.R.; Howitt, C.A.; Morell, M.K. Down-regulation of Glucan, Water-Dikinase activity in wheat endosperm increases vegetative biomass and yield. Plant Biotechnol. J. 2012, 10, 871-882. [CrossRef] [PubMed]

13. Ritte, G.; Heydenreich, M.; Mahlow, S.; Haebel, S.; Kotting, O.; Steup, M. Phosphorylation of C6- and C3-positions of glucosyl residues in starch is catalysed by distinct dikinases. FEBS Lett. 2006, 580, 4872-4876. [CrossRef] [PubMed]

14. Ritte, G.; Scharf, A.; Eckermann, N.; Haebel, S.; Steup, M. Phosphorylation of transitory starch is increased during degradation. Plant Physiol. 2004, 135, 2068-2077. [CrossRef] [PubMed]

15. Streb, S.; Eicke, S.; Zeeman, S.C. The simultaneous abolition of three starch hydrolases blocks transient starch breakdown in Arabidopsis. J. Biol. Chem. 2012, 287, 41745-41756. [CrossRef] [PubMed]

16. Blennow, A.; Engelsen, S.B. Helix-breaking news: Fighting crystalline starch energy deposits in the cell. Trends Plant Sci. 2010, 15, 236-240. [CrossRef] [PubMed]

17. Smith, A.M.; Zeeman, S.C.; Smith, S.M. Starch degradation. Annu. Rev. Plant Biol. 2005, 56, 73-98. [CrossRef] [PubMed]

18. MacNeill, G.J.; Mehrpouyan, S.; Minow, M.A.A.; Patterson, J.A.; Tetlow, I.J.; Emes, M.J. Starch as a source, starch as a sink: The bifunctional role of starch in carbon allocation. J. Exp. Bot. 2047, 68, 4433-4453. [CrossRef] [PubMed]

19. Zeller, S.L.; Kalinina, O.; Brunner, S.; Keller, B.; Schmid, B. Transgene $\times$ Environment Interactions in Genetically Modified Wheat. PLoS ONE 2010, 5, e11405. [CrossRef] [PubMed]

(C) 2017 by the authors. Licensee MDPI, Basel, Switzerland. This article is an open access article distributed under the terms and conditions of the Creative Commons Attribution (CC BY) license (http:/ / creativecommons.org/licenses/by/4.0/). 